Article

\title{
The Musical Bridge-Intercultural Regionalism and the Immigration Challenge in Contemporary Andalusia
}

\author{
${\text { Daniele Conversi }{ }^{1,2} * \mathbb{D} \text { and Matthew Machin-Autenrieth }}^{3}$ \\ 1 Department of Contemporary History, University of the Basque Country UPV/EHU, 48940 Leioa, Spain \\ 2 Ikerbasque, Basque Foundation for Science, 48013 Bilbao, Spain \\ 3 Faculty of Music, University of Cambridge, Cambridge CB3 9DP, UK; mm2085@cam.ac.uk \\ * Correspondence: daniele.conversi@ehu.es
}

Received: 1 November 2019; Accepted: 24 December 2019; Published: 30 December 2019

\begin{abstract}
The ideals of tolerance and cultural exchange associated with the interfaith past of Muslim Spain (al-Andalus) have become a symbol for Andalusian regionalism and for the integration of Moroccan communities. Nowhere is this more keenly felt than in the context of music. In cities such as Granada, Moroccan and Spanish musicians actively promote the ideals of intercultural dialogue through the performance of repertoires such as flamenco and Arab-Andalusian music that allegedly possess a shared cultural history. In this article, we examine the interrelationship between music and 'intercultural regionalism', focusing on how music is used by public institutions to ground social integration in the discourse of regionalism. Against a backdrop of rising Islamophobia and the mobilization of right-wing populist and anti-immigration rhetoric both within Spain and internationally, the authors consider how music can be used to promote social integration, to overcome Islamophobia and to tackle radicalization. We advance two arguments. First, we argue that the musical interculturalism promoted by a variety of institutions needs to be understood within the wider project of Andalusian regionalism. Here, we note that musical integration of Spain's cultural and historical 'Other' (Moroccans) into Andalusian society is promoted as a model for how Europe can overcome the alleged 'death of multiculturalism'. The preferential way to achieve this objective is through 'intercultural regionalism', envisioned as the combination of regional identity-building and intercultural interactions between communities that share a common cultural heritage. Second, we assess some of the criticism of the efficacy of al-Andalus as a model for contemporary intercultural exchange. Combining approaches in political science and ethnomusicology, we focus on one case study, the Fundación Tres Culturas (FTC). Through interviews with figures within the FTC, we examine why this model has become partly insufficient and how it is borne out in the sorts of musical activities programmed by FTC that seek to move beyond the 'andalusí' myth. We conclude by recognizing the continuing regional and international importance of this myth but we question its integrating capacity at a time of radical political, economic and environmental upheaval.
\end{abstract}

Keywords: nationalism; regionalism; interculturalism; Andalusia; Andalusi music; heritage; migrations; coexistence

\section{Introduction}

Since its foundation in the 19th and early-20th centuries, Andalusian regionalism (Andalucismo) has extolled its complex multifaith and multicultural heritage derived from the encounters of several cultural traditions, encompassing Arab, Berber, Latin/Spanish, Roma/Gypsy, Jewish and other influences. This 
regionalist tradition has appropriated the memory of a Golden Age preceding the Spanish Reconquest in 1492 and largely identified with the Caliphate of Córdoba under the Umayyad dynasty (929 to 1031), otherwise known as al-Andalus. In an attempt to distantiate Andalusian history from a broader Spanish, nationalist historiography, a somewhat utopian view of al-Andalus has been developed in popular culture, the media and even in historical scholarship ${ }^{1}$. This view frames al-Andalus (and the Caliphate in particular) as a celebrated era of interfaith encounters between Islam, Judaism and Christianity, and a 'culture of tolerance' (Dodds et al. 2010; Menocal 2012; Menocal et al. 2000). The ideals of tolerance and cultural exchange associated with al-Andalus have become integral both as a symbolic anchor for Andalusian regionalism and as a way of promoting the integration of immigrant communities within the region, even though a number of historians have sought to deconstruct the historical 'myth' of al-Andalus (Akasoy 2010; Catlos 2002; González Alcantud 2011, 2017; Soifer 2009).

In this article, we explore how this historical background is re-imagined through musical performance in the context of new challenges derived from recent migration trends into Andalusia particularly from Morocco. In his analysis of how al-Andalus has been instrumentalized for a variety of contrasting socio-political agendas in Spain (Andalusian regionalism, cultural tourism and Spanish colonialism in Morocco, 1912-1956), Eric Calderwood argues that public cultural organizations in Andalusia draw on the 'fiercely local tradition' of andalucismo (Calderwood 2014a, p. 36), a tradition that is based on the premise of cultural mixing in al-Andalus. Calderwood uses as a case study the Legado Andalusí institution, which he argues is underpinned by 'the Romantic desire to invent al-Andalus and the andalucista tendency to cast Andalusi culture as, at once, universal and quintessentially local' (Calderwood 2014a, p. 37). In a region that extols its alleged interfaith past, such institutions often promote the integration of Moroccan communities into Andalusian society as proof of the values of tolerance, diversity and intercultural dialogue that lie at the base of the Andalusian regionalist project and, by extension, of European values.

Nowhere is this more keenly felt than in the context of music. Across the region, Moroccan and Spanish musicians actively promote the ideals of intercultural dialogue through the performance of repertoires such as flamenco and Arab-Andalusian music that allegedly possess a shared cultural history (Machin-Autenrieth 2019, 2020). In this article we examine the interrelationship between music and 'intercultural regionalism' - we analyze how music is used by public institutions to ground social integration in the discourse of regionalism and an alleged Andalusian historical sensibility for intercultural dialogue. In particular, this intercultural modality gravitates around the heritage of flamenco and its combination with Moroccan Arab-Andalusian classical music (to be distinguished from regional or folkloric Andalusian music). Such an effort has not been built ex nihilo, but liaises with a pre-existing narrative of common origins and musical encounters between Spanish and Moroccan traditions in pre- and post-Reconquest Andalusia. This narrative continues to be part of a vibrant tradition of artistic creativity associated with the celebration of cultural distinctiveness and the building of musical bridges across the shores of the Mediterranean Sea (Glasser 2016). Combining approaches in political science and ethnomusicology, we focus on one case study, the Fundación Tres Culturas (Three Cultures Foundation, FTC), a public institution devoted to cultural diplomacy with the Arab world and in particular with Morocco. The majority of the article draws on theoretical reflections, secondary research and analysis of documentation pertaining to the FTC and related press materials. However, drawing on fieldwork conducted as part of Machin-Autenrieth's wider research project, the empirical basis for this article is supplemented by interviews with staff members from the FTC.

The article advances two main arguments. First, we argue that the musical interculturalism promoted by institutions such as the Fundación Tres Culturas needs to be understood within the wider project of Andalusian regionalism. Here, the musical integration of Spain's cultural and historical

1 While the Andalusi myth is inherent to Spain as a whole, it is most keenly felt in Andalusia because it is in this region where the Muslim past is most intensely experienced. 
'Other' (Moroccans) into Andalusian society is promoted as a model for how Europe can overcome the alleged 'death of multiculturalism' (Modood 2014; Ossewaarde 2014). The preferential way to achieve this objective is through 'interculturalism' and, specifically, a form of 'intercultural nationalism' (or in the Andalusian case, intercultural 'regionalism') envisioned as the combination of regional/national identity-building and intercultural interactions between communities that share a common cultural heritage. Framed by an idealized reading of Andalusia's past and its connections with Morocco, music becomes a symbolic bridge between the two territories marking out a perceived historical continuity from the coexistence of the three religions in al-Andalus to contemporary intercultural exchanges between Andalusians and Moroccans. Second, however, we argue that there has been criticism of the efficacy of al-Andalus as a model for contemporary intercultural exchange. As shown in interviews with figures at the FTC itself, some feel that the use of the past of al-Andalus as a model of tolerance obscures the contemporary realities of migration and social integration. In the final section, we shall briefly assess why this model has become partly insufficient and how it is borne out in the sorts of musical activities programmed by FTC that seek to move beyond the 'andalusí' myth.

\section{Historical Introduction: Andalusia and the Three Cultures}

Andalusia's Muslim past has become central to Andalusian identity and the region's accompanying political regionalism. Although Andalusian regionalism was conceived in the 19th century, it is most commonly associated with the work of the notary Blas Infante (1885-1936). His research into Andalusian cultural history was essential in shaping the Andalucista project, research that still informs a variety of cultural activities and political conceptions. In the book El Ideal Andaluz (1915), Infante proclaimed Andalusia's African origins and its Arab influences in opposition to the racial theories prevailing at that time in a war-torn, ultra-nationalist Europe (Infante 1976). More significantly, Infante placed meticulous emphasis on the region's Muslim heritage and the cultural achievements of al-Andalus as a constitutive emblem of what Calderwood calls an Andalusian 'internationalist nationalism [ ... ], which [Infante] explicitly set in opposition to the exclusivity of Catalan nationalist thought' (Calderwood 2014a, p. 37; 2014b). Moreover, Infante also emphasized the significant role of music (and specifically flamenco) in the shaping of Andalusian-ness. Indeed, flamenco was, for Infante, a relic of Andalusia's interreligious past-a direct result of the alleged cultural confluences between the different communities that cohabited pre- and post-Reconquest (Christians, Jews, Muslims, Moriscos and Gitanos) $)^{2}$.

The idea of an interfaith collective identity always refers back to a historical period predating the Reconquest-usually referred to as al-Andalus. The term al-Andalus is often used erroneously to refer to the parts of the peninsula governed by Muslims between 711 and 1492, until the Christian Reconquista was completed in $1492 .{ }^{3}$ Many Andalusian regionalists (including Infante) maintain that Andalusia knew its age of splendor not under the Christian kings but under its Muslim predecessors, culminating in the Umayyad dynasty and concluding with the Nasrid Kingdom of Granada (Reino Nazari de Granada) (est. 1230), under whose reign the Nasrid emirs built the Alhambra palace (1250). The Emirate was the last remnant of Muslim Iberia and its annexation during the Reconquest in 1492 sealed the fate of convivencia (the alleged peaceful coexistence and exchange between Christians, Jews and Muslims) with the end of interfaith coexistence. But how far was convivencia a tangible and clearly identifiable condition and mode of intercultural encounter?

2 Music is not the only artistic arena where one can find echoes of Andalusia's multicultural heritage. On the visual and architectural legacy of this 'culture of intimacy' forged between the three religions, see the beautifully illustrated book by (Dodds et al. 2010).

3 More accurately, al-Andalus was the name given to Muslim territories in the Iberian Peninsula under the Umayyad Caliphate based in Córdoba (711-1031), after which point the Peninsula fluctuated between the split rule of different Islamic kingdoms (the taifas) and temporary unification under the rule of the Almoravids (1085-1145) and Almohads (1232-1287). Al-Andalus as a term, however, is often used to refer to the entire period between 711 and 1492. 
Wolf describes convivencia as the 'peaceful coexistence' of the three Abrahamic religions and communities in pre-Conquest Spain and 'by extension the cultural interaction and exchange fostered by such proximity' (Wolf 2009, p. 72). 'Cultural interaction' here is central to a common reading of convivencia as a sort of historical model for contemporary interculturalism. The Republican historian and philologist Américo Castro (1885-1972) first used the term convivencia in 1948 to contest some of the nationalist tropes then prevalent about the primordial origins of Spanish identity, particularly after such tropes were being promoted abroad by the Franco regime (Castro 1948). The book was attacked by the pro-regime's historians as soon as it was published but was generally well received overseas, despite its lack of systematic research and Arabic sources (Wolf 2009). Yet, as Calderwood argues (Calderwood 2014b, 2018), the notion of convivencia and a Spanish-Moroccan 'brotherhood' rooted in the history of al-Andalus can also be seen as relics of Spanish colonialism in Morocco (1912-1956). Indeed, in an ironic twist of history, the rhetoric of historical intercultural dialogue that underpinned Infante's Andalucista ideology, and that ultimately led to his execution at the hands of Francisco Franco's forces in 1936, was also coopted as a tool by the Franco regime to legitimize Spain's continuing colonial presence in Morocco in the 1940s and 50s. In the lead up to Moroccan independence in 1956, there was increased emphasis on historical and cultural links across the Strait, as a way of consolidating colonial rule (García and de Larramendi 2002). Therefore, to a certain extent we need to question the assertion that al-Andalus and the idea of convivencia constitute a shared cultural heritage, when in many respects the promotion of interfaith encounters in Morocco can also be linked to a specific period of Spanish colonialism. Having said that, the notion of interfaith dialogue (convivencia) in al-Andalus and Arab-Andalusian music as a product of that dialogue, has become an integral part of Morocco's own project of postcolonial nation building. And, as Shannon notes, Arab-Andalusian music 'sonically connects Moroccans to medieval Iberia, echoing shared histories and genealogies that tie them directly to Europe and European culture' (Shannon 2015, p. 87).

Such a postcolonial reading of history is, however, not central to this article. Rather it is important to stress that the narrative of intercultural and interfaith coexistence in al-Andalus has now become an integral part of contemporary Andalusian regionalism. ${ }^{4}$ Despite the lack of politically significant linguistic differences (the region does not possess its own distinctive language unlike other Autonomous Communities in Spain), much evidence points to a milder variety of regionalism which is inspired by a strong sense of $e l$ ser andaluz (Andalusian 'being') rooted in the prominence of a multicultural Golden Age preceding the Reconquest, linguistic and cultural continuity with the region's Islamic heritage and, as we shall see, music as a formidable expression of cultural synthesis. Therefore, the 'myth' of al-Andalus clearly serves a unifying bridge-building purpose, independently from its partly fabricated origins and as a counterpart to the homogenizing Castilian narrative. The next section explores how the narrative of al-Andalus has been put under pressure by the dramatic rise of Moroccan migration into Spain, especially following Spain's accession to the European Economic Community in 1986.

\section{Immigration: A Challenge to Regional Identity}

The efficacy of al-Andalus as a model for contemporary intercultural tolerance and dialogue has been severely tested by recent immigration, particularly from Morocco. The first violent revolt against immigration in Spain occurred in the El Ejido municipality (part of the Almería province), where the local agribusiness employed immigrant laborers to pick vegetables and fruit. In February 2000, three murders at the hands of Moroccan immigrants unleashed protests with barricades, culminating

4 At times, Andalusian regionalism is described as a 'nationalism'. For example, the 2007 Statute of Autonomy defines Andalusia as a 'historic nationality' (nacionalidad histórica), while the earlier 1981 Autonomy Statute referred to Andalusia as simply a 'nationality' (nacionalidad). We should mention that the first Statute was approved through article 151 of the Spanish Constitution a unique process by which the region's autonomy was accelerated via a popular referendum after mass demonstrations leading to the status of 'nationality' shared by a few other Autonomous Communities. For the purposes of this article, we will stick to the term 'regionalism' so as to distinguish from Spanish nationalism more broadly. 
with street riots, injuries, casualties and material damages to immigrants' dwellings throughout the province. After these events, local authorities and the regional government sought to calm tensions and reintroduce a degree of greater tolerance. The integration of Moroccan communities into Andalusian society became a new challenge. As a result, the institutional and non-institutional rediscovery of the interfaith past of al-Andalus moved up the political agenda and became a model for the values of tolerance, diversity and intercultural dialogue that lie at the base of the Andalusian regionalist project. Moreover, this past has become a source of inspiration for interculturalism as the preferred framework for the social integration of immigrant communities, most notably Moroccans.

Why is the notion of interculturalism so important in Andalusia? As explored elsewhere in the case of Catalonia and Quebec (Conversi and Jeram 2017), interculturalism has been invoked as a major policy tool to 'integrate' immigrant minorities into a more respectful and dignified environment while, simultaneously encouraging regionally-based populist constituencies into accepting cultural and ethnic diversity as a resource, rather than as a threat. In Andalusia, the shift towards interculturalism-based immigration policies began more recently, marking a divergence from multiculturalism whose Anglo-Saxon roots do not sufficiently resonate with the local public. Interculturalism usually refers to a way of managing cultural diversity that seeks to combine both the recognition of difference and shared cultural values. Moreover, it implies a process of dialogue, exchange and the formation of 'new' identities and cultural practices from the interspace between different communities. Interculturalism has often been employed as an alternative approach to social integration vis-à-vis multiculturalism. As a concept (and an ideology), multiculturalism largely developed in Anglophone Canada (Kymlicka 1996; Kymlicka and Patten 2003; Taylor 1994), Australia (Smolicz 1995), Britain (May et al. 2004; Modood 2005; Parekh 2001) since the 1970s and, later, was used in some member-states of the European Union. ${ }^{5}$ In more recent years, the term multiculturalism has been subject to attacks at the international level from the mass media (Modood 2013). Also within academia, multiculturalism has been identified as a 'non-starter' and a 'spent' word (Levrau and Loobuyck 2018). Even though many have gone as far as to declare first 'the retreat' and then the 'death of multiculturalism' (Joppke 2004; Lentin 2014; Lentin and Titley 2011; Vertovec and Wessendorf 2010), 'to speak of the death of multiculturalism is to ignore the continuation of struggles that have been central to multicultural politics' (Nye 2007, p. 109). Nonetheless, since the 1990s, a 'backlash against multiculturalism' has occurred resulting in its retreat from public policies in various countries and its replacement, in some contexts, by the term 'interculturalism' (Levrau and Loobuyck 2018). Multiculturalism scholars, however, dissent on the degree of conceptual novelty interculturalism is supposed to offer in respect to multiculturalism, or whether it can truly provide a new paradigm. For Tariq Modood, 'interculturalist approaches suffer from an indeterminacy in the use of concepts such as local, place and proximity' (Modood 2018, p. 201). On the other hand, Taylor argues that 'the difference between the two is not so much a matter of the concrete policies but concerns rather the story that we tell about where we are coming from and where we are going' (Taylor 2012, p. 413). ${ }^{6}$ However, as we stated elsewhere (Conversi and Jeram 2017), 'interculturalism' assumes radically different meanings whether the term is used in Europe or in Quebec: in the former it has a 'localist' meaning, in the latter it carries a more 'majoritarian-nationalist' meaning, so that actually Modood criticizes the former, whereas Taylor refers to the latter. ${ }^{7}$

In the Andalusian context, the operational flexibility of the term interculturalism lends it a favorable status, as it is deemed to represent the Andalusian project in a more enhanced way, grounding it into a stable territory and connecting it to a past whose achievements have inspired artists and poets

5 According to Tariq Modood [personal suggestion to Daniele Conversi], no official, legally-binding document embraced the term 'multiculturalism' in the EU, including Britain, although in some countries it was discursively used to uphold possible social policies. Moreover, 'multicultural society', rather than 'multiculturalism', tended to be the preferred term (personal communication).

6 We recognize that, at least in some contexts, the term 'multifaithism' would be more appropriate in the case of Andalusia, but our article's emphasis is more strictly on cultural encounters and fusion. See (Modood et al. 2010).

7 Personal communication by Tariq Modood. 
throughout the Islamic world (Shamsie 2015). In particular, the term was constitutionally enshrined in the 2007 Statute of Autonomy of Andalusia, where immigration policy is specifically mentioned. Article 37 (Guiding Principles, 23) states: 'The social, cultural and religious coexistence (convivencia) of all people in Andalusia and respect for cultural diversity, beliefs and convictions, fostering intercultural relationships (relaciones interculturales) with full respect for constitutional values and principles' ${ }^{8}{ }^{8}$ These constitutional shifts need to be framed by the wider political context, given that the Spanish Socialists (Partido Socialista Obrero Español, PSOE) swept to power in Madrid in 2004 but were consequently defeated by a neoliberal government in 2008 led by the People's Party (Partido Popular, PP). However, the PSOE's largest regional branch was located in Andalusia, where it uninterruptedly remained the region's ruling party for over 40 years, from 1978 to 2019 under the name of the Spanish Socialist Workers' Party of Andalusia (Partido Socialista Obrero Español de Andalucía, PSOE-A). This political context provided the background under which the narrative of a tolerant Andalusia was rescued from attacks by the right, while the skeptics dismissed the entire notion of pre-Reconquest tolerance as a mere 'myth'.

In the aftermath of the December 2018 Andalusian regional election, when the far right anti-immigration Vox party emerged for the first time on the Spanish political scene, the tolerance narrative was challenged by a more xenophobic and centralist one. Vox gained 12 seats in the Andalusian Parliament and, as a result, won its first ever seat in the Spanish Senate. In the broader context of Vox's anti-immigration rhetoric, it is pertinent to note that the Andalusian areas in which the party gained its highest vote share were those with the largest immigrant communities that provide an invaluable labor force for agricultural regions (such as in Almería). In Seville, PSOE was defeated and a coalition government was formed between the PP and the Citizens' Party (Ciudadanos), just as both these parties moved further to the right to capture the ultranationalist electorate that had turned to Vox, which in turn supported the regional, PP-Ciudadanos coalition. However, the 2007 Statute of Autonomy of Andalusia has remained firmly in place ensuring the continuation of previously established cultural activities of institutions like the FTC with their unyielding support for interculturalist policies. Here, the history of al-Andalus still provides a useful model for the intercultural activities of organizations such as the FTC, where artistic phenomena (such as music) are an integral tool. And, it is against this political backdrop of the rise of right-wing populism and anti-immigration rhetoric vis-à-vis the interculturalism of institutions such as the FTC that we place our analysis of music.

We define 'musical interculturalism' as the use of music as an institutional (as well as non-institutional) strategy to promote social integration, to overcome Islamophobia and to tackle radicalization, framed by the ideology of intercultural dialogue. And music is a powerful vehicle for the promotion of what we are calling 'regionalist interculturalism' (and, interchangeably, 'intercultural regionalism') as a variety of the 'intercultural nationalism' previously studied in Catalonia and Quebec (Conversi and Jeram 2017). Intercultural nationalism has been defined as 'the core doctrine through which (sub-state) nationalist discourse has been articulated in relation to immigration' (Conversi and Jeram 2017, p. 53). By extension, we use regionalist interculturalism (and 'intercultural regionalism') (RI) to refer to the regionalist-informed social policies adapted in a context where regionalism is more often invoked than nationalism. RI can thus be envisioned as the combination of regional identity-building and intercultural interactions between communities that share a common cultural heritage. In Andalusia, RI shapes the promotion of intercultural dialogue and social integration through a regionalist reading of the past that is rooted in the alleged history of religious and cultural pluralism and exchange in al-Andalus. In this sense, the political project of promoting dialogue through interculturalism is deeply intertwined with, and in many respects inseparable from, the project of Andalusian regionalism.

8 https://www.boe.es/buscar/pdf/2007/BOE-A-2007-5825-consolidado.pdf. 


\section{Understanding Musical Interculturalism in Andalusia}

By considering the case of the Fundación Tres Culturas, we now focus on how public institutions draw on music as a vehicle to shape a form of interculturalism built on the symbolic framework of al-Andalus as a space of intercultural coexistence and exchange. Indeed, as will be developed below, music has become one of the most representative examples of the FTC's cultural activities and is an integral part of the institute's programs aimed at intercultural dialogue and the social integration of Moroccans in Andalusia.

Jonathan Shannon (Shannon 2015) argues that in the post-9/11 context of increased immigration and the 'global war on terror', music has become a prominent vehicle for convivencia as a 'good to think' principle. He states: 'Andalusian convivencia remains one of the enduring cultural legacies of al-Andalus, relevant not only to narratives of the past but for a variety of contemporary projects of multiculturalism that draw on it-indeed they have helped to construct it as a modern phenomenon' (Shannon 2015, p. 29). In other words, historical narratives, either based on myth or ascertainable fact, function as propulsors of a Good Society and are hence essential to the functioning, cohesion and development of these societies (Armstrong 2004; Smith 2003). Particularly important is the myth of a Golden Age, identifiable as a past society in which the ultimate values were once upon a time embodied in ideal (or idealized) political structures and social practices (Armstrong 2017, 2004; Hutchinson 2015; Smith 2000, 2003). Golden Ages are usually followed by long periods of decadence, and nationalist intellectuals and politicians have set as their major goal the recreation of such a Golden Age within a specific nation or region. In Andalusia, music has become a primary driver in the recreation of al-Andalus as a Golden Age. Before moving to an analysis of musical activities at the Fundación Tres Culturas, it is worth briefly contextualizing the musical manifestations of al-Andalus in contemporary Andalusia, as the FTC frequently program performances of Arab-Andalusian music and its derivatives.

\section{Music as a Bridge: Música Andalusí and Flamenco}

Arab-Andalusian classical music developed initially in Spain and Portugal during the Muslim occupancy and is today performed throughout the Maghreb, where it was introduced in the 15th and 16th centuries by refugees expelled after the Reconquest. It is important to keep in mind that the generic label Arab-Andalusian music (or música andalusí in Spanish) is a European categorization that emerged from the vestiges of colonial rule in North Africa (Fernández Manzano 1993, 2012; García Cortés 1996, 2018; Guettat et al. 1999; Poché 2005). As such, the term refers to a range of discreet and unique genres and repertoires that stretch across the Maghreb and into the Middle East (Nair 2006). For example, the text, musical forms and melodic structures of Arab-Andalusian music in Morocco (known nationally as al-âla) differ from the ma'luf tradition as performed in Tunisia. Even within national traditions, distinct local schools exist, such as the Fez, Tetouan and Rabat schools in Morocco. What is a general constant, however, is an origins narrative that positions Arab-Andalusian music (in whatever form it might take) as a symbol of interfaith dialogue (in al-Andalus and, subsequently, across the Mediterranean carried by the migration of moriscos to North Africa).${ }^{9}$ For Maghrebi practitioners and devotees of Arab-Andalusian music along the Southern Mediterranean coast, the memory of the diasporic origins in pre-1492 al-Andalus/Sefarad is a 'central part of the practice' (Glasser 2015; Guettat et al. 1999; Poché 2005).

In a similar vein, flamenco (Spain's most iconic music and dance tradition) is often linked to Andalusia's historical and cultural past. While flamenco is traditionally associated with Andalusia's deeply-rooted Gitano (Gypsy) community, in recent years Andalusian public institutions and the regional government itself have co-opted flamenco as the region's 'core value' and premier identity symbol (Aix Gracia 2014; Conversi 2018; Machin-Autenrieth 2017; Washabaugh 2013). In other words,

9 For recent scholarship on the different Arab-Andalusian traditions of the Maghreb see: (Chaachoo 2011; Ciantar 2012, 2016; Corfis 2009; Davila 2012, 2013; Glasser 2016; Reynolds 2009a, 2009b; Shannon 2012, 2015). 
one can say that flamenco has been chosen as a 'core value' of regional identity on a similar line as the Catalan and Basque languages have been at various times considered pivots of their respective national cultures (Conversi 1997). Yet, at the same time the 2007 Statute of Autonomy mentions 'the recognition and use of the Andalusian language modality, in their different varieties' (Article 213 of the Statute of Autonomy for Andalusia). Additionally, due to their lexicon and phonetics these dialects are popularly attributed to the region's past Islamic heritage and are thus viewed as a sign of historical and cultural continuity.

A large part of flamenco's relevance for Andalusian identity construction is its alleged roots in the region's multicultural past with numerous musicians and scholars espousing influences taken from Muslim and Jewish repertoires. Indeed, Blas Infante himself (the aforementioned 'father' of Andalusian regionalism) developed the idea that flamenco was inherited from al-Andalus as well as intercultural exchanges between Morisco and Gitano communities following the Reconquest. We should consider here a third ethnic and cultural element, namely the music and musicality of the Gitanos/Gypsy/Roma groups inhabiting the region for several centuries and having become some of the most reliable repositories of this intercultural tradition, an issue that has been explored elsewhere (Conversi 2018; Goldberg 2019; Leblon 2005; Paetzold 2009).

Most salient for this article, is the widespread belief that flamenco shares a number of historical and musical similarities with Arab-Andalusian music (Cruces Roldán 2003)—that they are both cultural by-products of al-Andalus. While it is easy to dismiss this idea as an act of historical fantasy (particularly given the fact that flamenco as a standardized genre only emerged in the 19th century), it is undeniable that there are similarities between the traditions in terms of mode, rhythmic structure and vocal performance. It is these similarities and the symbolic framework of a shared cultural heritage that have given rise to a number of fusion projects between these two traditions. For example, the Gitano singer and musician Juan Peña 'El Lebrijano' (1941-2016) collaborated with the Andalusian Orchestra of Tangier in the album Encuentros (1985), which stands as a celebration of cultural and religious diversity, as well as a unique fusion between flamenco and classical Arab-Andalusian music. El Lebrijano continued to collaborate with Moroccan musicians for many years with albums like Casablanca (1998), Puertas abiertas (2005) and Dos Orillas (2014, recorded live at the Central Theater of Seville). Fusions between flamenco and Arab-Andalusian music date back even earlier with the production Macama jonda (1983), written by the Gypsy poet, playwright, academic and essayist José Heredia Maya (1947-2010), the first Gypsy professor in a Spanish University and a theorist of the alliance between literature, anthropology and theatre (Heredia Maya 2004). ${ }^{10}$ A work ahead of its time, Macama jonda was the first fusion of flamenco with Arab-Andalusian music (Machin-Autenrieth 2019), portraying the marriage between a Christian Andalusian and a Muslim Moroccan, 'anticipating what, 20 years later, will be called an alliance of civilizations'. ${ }^{11}$

\section{Musical Interculturalism at the Fundación Tres Culturas}

The Fundación Tres Culturas (FTC) was founded in 1999 as a joint initiative between the Andalusian and Moroccan governments. Based in the former 'Moroccan Pavilion' originally constructed as part of the Universal Exposition in Seville in 1992, the FTC stands as an emblem of inter-governmental cooperation between Spain and Morocco. At its core, the FTC is a cultural organization, financed through public and private funding and dependent on the Junta de Andalucía, that is engaged in cultural diplomacy between Spain and the Arab world. Its key objectives are the promotion of intercultural dialogue across the Mediterranean generally and between Spain and Morocco specifically, as well as facilitating the social integration of immigrants (particularly Moroccans) within Spanish

10 https://elpais.com/diario/1983/04/18/cultura/419464816_850215.html.

11 https://baxtalo.wordpress.com/2010/01/18/se-nos-marcho-jose-heredia-maya/. For an in-depth analysis of this production see (Machin-Autenrieth 2019). 
society, above all in Andalusia. Moreover, as its director José Manuel Cervera Gragera has noted in a recently published interview (Matute 2019), ${ }^{12}$ the expressed intention of the institution is to valorize and promote the historical relationship between Andalusia and the Arab world, particularly with Morocco. A common assertion is that the institution is unrivalled in Europe for its ability to facilitate intercultural dialogue across territories and between governments. Cervera Gragera states that the FTC is a model in Europe and that there is currently no other institution that has 'one foot in Africa and one in Europe' (Matute 2019). Framed against the wider context of geopolitical conflict, the refugee crisis and threats to democracy across the Mediterranean, the FTC positions itself as a vehicle for social and political change in a region whose history is as much characterized by conflict as it is by confluence. However, according to Cervera Gragera the alleged uniqueness of the FTC in Europe is not just a consequence of good practice but is a direct outcome of the historical conditions afforded to the institution's acts of cultural diplomacy by dint of Andalusia's multicultural past.

How can such a relatively small Andalusian institution help to shape broader Mediterranean geopolitics? In what capacity? In response to such questions, Cervera Gragera replies: 'Andalusia has a unique potential to intervene in these conflicts, which no-one else in Europe has. Our principal capital is the sympathy with which the Arab and Hebrew worlds see us. Keep in mind that for the first [Arabs] we have been al-Andalus and for the second [Jews] we have been Sefarad. Andalusia, therefore, has never lost this bond with its past and has always maintained dialogue with these cultures' (Matute 2019). Therefore, at the center of the FTC's vision lies a fundamental principle of the Andalusian doctrine of regionalism: the region's multicultural past and its capacity to engender dialogue and exchange between the three major monotheistic religions. And by extension, Cervera Gragera sees the Andalusian region as unique in Europe and thus well positioned to promote peace and dialogue in the Mediterranean region.

As discussed, the andalusí 'myth' with its utopian reading of Andalusia's past has frequently been employed by Andalusian regionalist figures, such as Blas Infante. However, given the devolution of further autonomous powers to the Andalusian Government in the 2000s and, simultaneously, an increase in Moroccan migration into the region, the andalusí 'myth' has become a more fundamental component of how the Andalusian Government constructs a cohesive regional identity, by tackling straightforwardly the intensification of anti-immigration rhetoric. Geopolitically, it also serves the strategy of promoting the region's interests abroad (particularly in the Arab world), while strengthening a regional 'brand' in terms of heritage politics and cultural tourism. In this context, publicly-funded institutions, such as the FTC, are central to the promotion of al-Andalus as 'good to think' (Shannon 2015); as a useful model for contemporary intercultural relations despite its contested historical basis. ${ }^{13}$

Cervera Gragera notes that the institute's main intention is 'to evoke [ ... ] the spirit of what once was al-Andalus and Sefarad' (Matute 2019). In this way, the ideals of tolerance, exchange and dialogue that characterize the spirit of al-Andalus are stripped of any historical accuracy and upheld as a regionalist model for what positive intercultural exchange could look like. Against this historical background, culture (and particularly music) remains the institution's primary vehicle for facilitating dialogue and diplomacy by harnessing the historical capital of al-Andalus. Cervera Gragera continues: 'Culture allows us to do things that politics would not allow us to do. In recent years, we have organized many cultural encounters between Jews, Muslims and Christians through which success would have been difficult to achieve if they were based on political terms' (Matute 2019). Here, Cervera Gragera alludes to the central role of cultural diplomacy as a way of facilitating dialogue and exchange between groups that may be difficult to achieve politically. As a result, the FTC hosts a range of cultural and

12 https:/www.jotdown.es/2019/04/jose-manuel-cervera-la-extrema-derecha-europea-esta-hoy-disfrazada-denacionalismo/. See also (Cruces Roldán 2003), pp. 123-27.

13 Another public cultural organisation that promotes the history of al-Andalus as a model for intercultural dialogue is the Legado Andalusí Foundation (http://www.legadoandalusi.es), as discussed by Calderwood 2014 a. 
academic activities including cinema showings, conferences, workshops, artistic exhibitions, theatre productions, literary festivals and, of course, concerts and musical workshops.

\section{Arab-Andalusian Music and Raising Awareness of the Moroccan 'Other'}

At the forefront of the FTC's musical activities are concerts and training courses in musical traditions that can trace their lineage to al-Andalus, particularly Arab-Andalusian music and its Moroccan derivative, al-âla. In recent years, there has been increased interest in Spain towards Arab-Andalusian music not simply as a 'foreign' musical form but one that is deeply rooted in the country's own cultural history. And quite predictably, a lot of this increased interest has been focused in Andalusia with cities such as Córdoba, Granada and Seville laying claim to certain strands of the Moroccan Arab-Andalusian repertoire that left with the staggered emigration of Muslims and Jews following the disintegration of the taifa kingdoms from around the 12th century and the eventual expulsion of Moriscos in the early 17th century. Since its founding, the FTC has been at the forefront of promoting Arab-Andalusian music through its cultural activities and the tradition is viewed by many within the institution as a crucial vehicle for cultural diplomacy between the two shores of the Mediterranean and between Moroccan and Andalusian communities on the Peninsula. In an interview, the strategic planner for the FTC, Antonio Chaves told Machin-Autenrieth: 'we believe that we have to take advantage of Arab-Andalusian music as another component of our work of cultural diplomacy. And that's why I'm saying it is a strategic element. We work in cultural diplomacy and, for us, Arab-Andalusian music is another example of our strategy for cultural cooperation' (4 July 2018). ${ }^{14}$

But in what ways does Arab-Andalusian function as a tool for cultural diplomacy in the context of intercultural relations in southern Spain? To answer this question, it is worth exploring in more detail the sorts of projects in which Arab-Andalusian music appears at the FTC. Rarely does the institute just schedule performances or music courses on their own: normally Arab-Andalusian music is integrated into larger flagship programs and projects run by the institute that have broader geopolitical and intercultural aims. For example, Arab-Andalusian music has featured as a regular part of the Alcántara program, a series of projects and events that focus on building 'bridges for dialogue and convivencia' between Andalusia and Morocco. The program emerged out of a strategic partnership between the FTC and the Moroccan ministry for Moroccan residents abroad. According to Chaves, the primary objective of this program is 'to work towards improving the image of Morocco in Spain and also to work towards improving the life conditions of Moroccans that live in Spain' (4 July 2018). ${ }^{15}$ This is particularly evident in the annual 'Mes de Marruecos' and 'Ramadán entre Culturas' events that are held as part of the Alcántara program. Both events are scheduled to raise awareness of Moroccan (and by extension Arab and Muslim) culture and customs and to engender points of commonality and dialogue between 'host' and 'guest' communities in Andalusia. These events always feature Arab-Andalusian music of some form or other, and in recent years courses in Arab-Andalusian music theory and appreciation have been led by the Tetuani musician and educator Amin Chaachoo, followed by a concert.

First and foremost, the aim of these concerts and workshops is to improve the image of Moroccan culture within Spain and to provide cultural and institutional space for Moroccans to foreground an important component of their own national cultural identity. Yet more than this, Chaves noted that through these events 'we have to make Arab-Andalusian music known as an element not only unique to Morocco but also an element that is part of a common Andalusian culture' (4 July 2018). ${ }^{16}$ It is here that the idealized image of al-Andalus that lays at the root of a broader shared Andalusian-Moroccan

14 'Entendemos que tenemos que aprovechar la música andalusí como un elemento más de nuestra labor de diplomacia cultural. Por eso te digo es un elemento estratégico. Trabajamos en la diplomacia cultural, y para nosotros la música andalusí es una labor más de nuestra estratégica de cooperación cultural'.

15 'Trabajar para mejorar la imagen de Marruecos en España y también trabajar para mejorar las condiciones de vida de los marroquíes que residen en España'.

16 'Hay que darle conocer la música andalusí como un elemento no solamente propio de Marruecos, sino un elemento también propio de la cultura común andaluza'. 
cultural sensibility is foregrounded in how these musical events are promoted. For example, following a course offered by Amin Chaachoo in 2019, there was a concert in which 'the students put into practice the knowledge acquired during the course with a musical show that represents the tolerance that existed in the epoch of al-Andalus in which Jews, Christians and Muslims came together to express the same artistic sentiment ${ }^{\prime}{ }^{17}$ Here, the notion of tolerance and exchange embodied in the narrative of al-Andalus finds a perfect vehicle in the context of Spaniards learning the music of the Moroccan 'other,' framed by a wider institutional agenda and discursive context that seeks to tackle rising Islamophobia and radicalization. In effect, music is employed by the FTC as a cultural 'space' in which both Spaniards and Moroccan can push back against and even negate these negative social phenomena that have arisen in response to increased Moroccan migration and rising populist nationalism. Indeed, as Chaves pointed out, the main objective of using Arab-Andalusian music in this way is to present this music to Andalusians as their own cultural heritage that can be shared with Moroccans, a key tenant of the philosophy of interculturalism.

\section{A Fusion of Cultures: Musical Interculturalism at Work}

Arguably where musical interculturalism at the FTC really comes into its own is in the context of fusions between flamenco and Arab-Andalusian music as touched on above. Such encounters are built on the idea that both traditions can trace their historical lineages to the musical repertoires and practices of al-Andalus and Morisco culture following the reconquest. Some scholars (Karl 2012, pp. 170-230, 2014; Machin-Autenrieth 2020) have examined the relevance of these fusion projects in the context of grassroots interactions between Spanish and Moroccan musicians and how they capitalize on the cultural monopoly of flamenco as a form of social integration. Moreover, this research has revealed some of the ways in which Moroccan musicians might need to exoticize their musical practices-through the use of bell dancing for example see (Karl 2014), thus marking out their difference, despite the underpinning rhetoric of a shared cultural heritage. It is important to recognize, however, that we are primarily concerned with how public institutions (and the FTC in particular) harness musical exchanges of this sort in the promotion of a particular regional reading of history as the basis for interculturalism, rather than the on-the-ground negotiations between musicians. Like Arab-Andalusian music proper, flamenco-andalusí fusions are a relatively regular part of the FTC's programming and feature predominantly as part of wider projects that seek to encourage cultural exchange between communities and improve the social integration of Moroccans. For example, in the 2017 edition of 'Mes de Marruecos', the Granada-based Moroccan musician Hamid Ajbar performed in a charity concert in solidarity with refugees and for the promotion of cultural dialogue. ${ }^{18}$

When Machin-Autenrieth asked Antonio Chaves the relevance of these fusions for the institute and their capacity for generating dialogue, he maintained a common trope that flamenco and Arab-Andalusian music have a 'common trunk'. He described these fusions as a way of integrating Moroccans into Andalusian society, of facilitating cross-cultural dialogue. In particular he referred to a student concert that was held following the Arab-Andalusian music course as part of the 'Ramadán entre culturas' (2018) event and that flamenco was, unexpectedly, included as part of the concert. He noted how well it was integrated into the performance and how Moroccan members of the audience clearly identified with flamenco, given its relative popularity in Morocco and the idea that the tradition is linked to Morocco's own musical history. Such fusions also enable Arab-Andalusian music to gain more traction and popularity with Spanish audiences, because a tradition that is largely unknown to the majority of Spaniards is made more accessible and palatable through its fusion with a more familiar and culturally-relatable music — that is, flamenco. Ultimately, for Chaves, such fusions are highly symbolic

$17 \mathrm{http}: /$ tresculturas.org/actividad/una-muestra-musical-clausura-el-iv-curso-de-musica-andalusi/. For a full video of the concert following the 2018 courses, see https://www.youtube.com/watch?v=Cyrw5Ca0vaY.

$18 \mathrm{http}: / /$ tresculturas.org/actividad/concierto-solidario-favor-los-refugiados-hamid-ajbar-flamenco-fusion/. 
of the broader aims of the FTC: 'it is the perfect excuse, because we can encounter [understand] each other through music-it is possible. If we can encounter [understand] each other in music, why can't we encounter [understand] each other in other types of cultural spaces?' (4 July 2018). ${ }^{19}$

This ability to 'encounter' (or understand) one another and to create a cultural 'space' through flamenco-andalusí fusions, for Chaves, is key to music's efficacy as a tool for interculturalism. Indeed, he argued that 'our institution appeared precisely so that the cultural communities that are here arrive at a moment when they can encounter each other and so that this intercultural interaction exists. In other words, our role as an institution has to be the generation of spaces of encounter for citizens. Music is the tool' (4 July 2018). ${ }^{20}$ The underlying presumption here is that music, perhaps more so than any other cultural phenomenon, creates a mutual space of encounter in which those from distinct cultural backgrounds can come into creative dialogue and thus 'understand' each other at an artistic and cultural level, when such understanding might be elusive at a linguistic or social level. This is not an unknown phenomenon and indeed there are innumerable examples around the globe of music being used in the capacity of cross-cultural dialogue, peace-building and conflict resolution. But what is interesting in this case is how an idealized reading of history (that is, tolerance and exchange in al-Andalus) is interwoven into these musical encounters in such a way that the resultant artistic product is viewed as an outcome of history. At another level, this musical metaphor for an alleged shared cultural history between Andalusia and Morocco becomes the basis for a model of regionalist interculturalism, such as that promoted by the FTC, as being unique to the Andalusian region.

\section{The Efficacy of the Andalusí Myth and Regionalist Interculturalism}

Thus far, we have considered the ways in which the FTC has drawn on Arab-Andalusian music and its fusion with flamenco to promote 'regionalist interculturalism' - that is, intercultural dialogue between host and migrant communities based on an idealized reading of al-Andalus as a Golden Age of interreligious exchange. Moreover, Andalusia is promoted as unique in Europe where the past becomes a model for coexistence and interculturalism in the present. Music, and specifically the musical traditions of al-Andalus, has become a key vehicle in promoting this message. However, the broader efficacy of some of the musical projects put on by the FTC could be questioned, including the claims that such collaborations can help to prevent radicalization and Islamophobia. While it is true that these intercultural initiatives allow intercultural spaces to emerge, mass media and the Internet offer scarce windows for their wider popularization. The recent discovery of false Facebook accounts and radical right social networks with millions of supporters throughout Spain, like the Unidad Nacional Española (UNE) with over 1.2 million followers, show how the intercultural narrative has insufficiently suffused and shaped the media or, at least, been unable to stem far-right radicalism. ${ }^{21}$ Consequently, the sort of people who are likely to attend FTC events are probably those that are already interested in the cultural history of al-Andalus, as well as those who already have positive attitudes towards Moroccan culture and, possibly, immigration. The sorts of communities most prone to take on board mounting Islamophobia are unlikely to be those interested in Arab-Andalusian music and the past of al-Andalus, however these may be packaged.

Against this backdrop, within the FTC itself there exists a degree of skepticism around the efficacy of the andalusí myth and the wider social relevance (especially for Moroccans and in terms of Spanish perceptions of Moroccan immigration) of Arab-Andalusian music and its fusions with flamenco. When asked about the social significance of the sorts of collaborative projects that the

19 For recent scholarship on the different Arab-Andalusian traditions of the Maghreb see: (Chaachoo 2011; Ciantar 2012, 2016; Corfis 2009; Davila 2012, 2013; Glasser 2016; Reynolds 2009a, 2009b; Shannon 2012, 2015).

20 'Nuestra institución surge precisamente para que las comunidades culturales [que] estén aquí lleguen a un momento en que se encuentren y exista esta interacción de interculturalidad. Es decir, nuestro papel como institución tiene que ser la generación de espacios de encuentro ciudadanos. La música es la herramienta'.

21 For some detailed data see 'Far Right Networks of Deception', Avaaz Report, 22/05/2019 (https://avaazimages.avaaz.org/ Avaaz\%20Report\%20Network\%20Deception\%2020190522.pdf). 
FTC programs, one informant told Machin-Autenrieth: 'it doesn't mean anything, because it isn't real, it isn't contemporary, because it is much more interesting to sit down and look at what young Moroccans and young Andalusians have in common than to praise Averroes again' (28 April 2015). ${ }^{22}$ Therefore, alongside the andalusí-focused cultural activities we have described, the FTC has also branched out into other areas. This was particularly evident in one of the institute's major projects carried out in 2014, with the support of European Regional Development funds, called CREAMOS, Programa de Creación Artística entre Andalucía y Marruecos con Objectivos Sociales. Like many of the FTC's projects, CREAMOS was based on collaborative encounters, exchanges and exhibitions across a range of cultural activities with events held in both Andalusia and Morocco. However, this time the connection with the historical narratives of al-Andalus and the 'three cultures' narrative were absent. ${ }^{23}$ Within the framework of this project, in March and April 2014 an art exhibition called 'Arte Urbano $14^{\prime}$ was held in Tarifa and Seville, ${ }^{24}$ which was inaugurated with hip hop performances by Moroccan and Andalusian artists, including Moroccan musicians who have emerged from more socially and economically marginalized communities. Hip hop or rap music is an American genre initially born amongst Afro-Americans in the Bronx neighborhood of New York City in the 1970s, but has since then spread across the globe along with graffiti writing, break dancing and DJing scratching, through policies and practices of socio-cultural Americanization (Bonnett 2006). ${ }^{25}$

In many respects, these sorts of events depart from the discursive and symbolic framing of the FTC (that is, al-Andalus), a framing that might restrict the institute's appeal to a certain social demographic. Indeed, it is important to recognize the broader class implications that arise from the social institutions that underpin both Arab-Andalusian music and flamenco. As Shannon argues, 'in a market saturated with popular music from Europe and the Arab East, many middle-class and elite Moroccans are turning to [Arab]Andalusian music as a way of reinforcing their connections with a Moroccan national "tradition"' (Shannon 2015, p. 107). In line with the work of other scholars (Davila 2013; Karl 2012, 2014), Shannon illustrates how despite being broadly defined as a 'national' music, Arab-Andalusian music is usually associated with elite institutions in Morocco, most notably the monarchy and wealthy families who can trace their lineages to al-Andalus. Therefore, for younger Moroccans and those from working class backgrounds, the tradition may have less social significance than popular genres such as raï and hip hop. Moreover, it could also be argued that fusions between flamenco and Arab-Andalusian music present a somewhat peculiar crossing of social and class distinctions, given the former's evolution amongst marginalized Gitano and lower class communities and the latter's ties with the elite and monarchical structures in Morocco. As such, the FTC has sought to broaden its appeal, to intervene in harder-to-reach immigrant communities (for example, in working class or agricultural areas) and to raise awareness of social issues in the Mediterranean such as illegal migration and poverty. In themselves, however, they cannot provide an antidote to existing problems, as anti-Muslim sentiments can, and do, often coexist with cultural initiatives aimed at cultural rapprochement.

Beyond issues of social class and appeal, the desire to broaden the musical activities of the FTC and move beyond Arab-Andalusian music and its flamenco fusions, appears to be linked to a general uneasiness around how al-Andalus is promoted by the FTC. When asked to what extent al-Andalus formed the symbolic basis for the FTC's activities, one interviewee said: 'It isn't the base ... well, at the moment it is probably the political base, because that is how Spain sells itself; Spain sells itself as if we are a place of encounter, a place of coexistence [ ... ] and certainly it [the idea of al-Andalus] resonates with lots of people. But it is also true that the same person, my mother

22 'No significa nada, porque no es real, no es contemporáneo, porque es mucho mas interesante sentarse a ver que tienen en común los jóvenes de Marruecos con los jóvenes andaluces que aladar otra vez a Averroes'.

23 For more information on the CREAMOS project's activities and objectives, see: http://tresculturas.org/proyecto-creamos/.

24 http://tresculturas.org/fundacion/noticia/proyecto-creamos-arte-urbano-raperos-andalucia-marruecos/. Also see: https: //www.webislam.com/articulos/93344rap_de_andalucia_y_marruecos_portavoces_de_las_dos_orillas.html.

25 For a broader and well-known reading of this phenomenon, see (Barber 1995). 
could tell you how beautiful al-Andalus was but can't stand having a Muslim neighbor' (28 April 2015). ${ }^{26}$ Here, the interviewee recognized that politics in Spain (and Andalusia specifically) is broadly geared towards instrumentalizing the history of al-Andalus to promote the country as a space of tolerance and convivencia. However, although the myth is relatively diffused in popular culture, it is precisely here that it is being challenged by a contrasting monocultural Spanish-only narrative and myth. While the FTC seems to epitomize the wider political institutional appropriation of history, there are grounds for questioning the view that people might be generally sympathetic to the idea of Andalusia's multicultural history. The success of the far right in Andalusia seems to illustrate this weakness. And this was clearly articulated in how the interviewee referred to the idea that a person might like the concept of al-Andalus in the past but dislike the reality of multiculturalism (and in particular Muslims in Spain) in the present.

What appears to be the issue here is a general questioning of the model of regionalist interculturalism and the idea that a positive reading of al-Andalus can (or even should be) a model for contemporary interculturalism. Another member of the FTC related this issue directly to music: 'I prefer to show something contemporary so that the moor you have in front of you ${ }^{27}$ isn't a moor wearing a jellaba, playing old music but is a guy who is like your son [ ... ]. This is the problem ... to feed this myth of al-Andalus, and this crazy type of musical project [flamenco-andalusí] feeds this myth that everything was perfect, when it wasn't' (28 April 2015). ${ }^{28}$ This quotation illustrates both an anxiety to comply with the dominant Westernizing urge and a certain degree of impatience with the ways in which music is used to paint a utopian view of al-Andalus, which this individual, at least, feels is somewhat outdated. More broadly, both this quotation and the previous one give the sense that, while people may be attracted to the idea of al-Andalus as an emblem of tolerance and dialogue, this does not necessarily extend to positive views of Muslim and Moroccan immigrants in Spain today. While these interviews reflect isolated, individual views, they still raise questions around the efficacy of regionalist interculturalism to shape public perceptions at a popular level. Finally, they show that the way popular culture is framed by the media with their pressure to conform to global 'standards' can impinge upon interculturalism and the project of using music as a cultural bridge.

\section{Conclusions}

By focusing on 'Andalusian' music, particularly Andalusian-Moroccan fusions, this article has explored the use of interculturalism by regional institutional actors as a tool for creating a novel framework of tolerance and coexistence. Myths, whether supported by historical research or not, play a central role in shaping political cultures, social policies and good governance. As recognized across the social sciences, particularly in nationalism studies (Leerssen 2015; Leoussi and Grosby 2006; Martin 2014; Smith 1991, 1998, 1999), myths play a key function in building cohesive societies based on trust and mutual understanding, so that the organization of vital matters that shape the day-to-day life can proceed smoothly. We should also understand that politically successful ideas and policies are generally based on myths and subconscious assumptions (Billig 1995).

According to the al-Andalus and regionalist narrative, music is a 'core value' of regional identity, so that fusions between flamenco and Arab Andalusian music work as a bridge between cultures

26 'No es la base ... . bueno, la base política seguramente en este momento sería, porque así es como España se vende a si misma, España se vende a si misma como nosotros somos un lugar de encuentro, un lugar de convivencia [ ... .] es cierto que resuena [the idea of al-Andalus] con muchísima gente. Pero también es cierto que la misma persona, mi madre te puede decir qué bonita al-Andalus pero no soporta tener un vecino musulmán'.

27 The interviewee was using the term moor, a pejorative term often used to refer to Muslims or Moroccans, but also to refer to the Arabs and Berbers that conquered Spain in 711AD. Ironically, this is a term that some Spaniards might use when referring to a Moroccan neighbour or colleague.

28 'Prefiero enseñar algo contemporáneo para que el moro que tienes adelante, no sea un moro que va con la chilaba, tocando música antigua pero es un tío que ves como tu hijo. [ . . . Es el problema ... alimentar este mito de al-Andalus y este tipo de proyecto musical descabellado alimenta el mito de que todo era perfecto, pero no era'. 
and geopolitical spaces, as well as providing continuity with a usable past and mythical Golden Age. Pre-1492 Andalusia is certainly not unique in being presented as a Golden Age of plural coexistence and interfaith encounter. The pathbreaking work of Mark Mazower (Salonica, City of Ghosts: Christians, Muslims and Jews, 1430-1950) identifies with outstanding clarity how religious, ethnic, cultural and linguistic pluralism was for over five centuries a defining feature of daily life in the region and city of Salonica until the advent of twentieth century homogenizing nationalism (Mazower 2005). Nonetheless, the andalusí narrative carries considerable cultural and political weight in the promotion of intercultural exchange between different communities.

However, we have also explored some of the limits of this narrative: first, its message of tolerance does not always reach areas of the lower-class population in Andalusia and so cannot avert an opposing homogenizing Christian-only narrative and mono-cultural nationalism, as expressed by the rise of far-right populism. Secondly, we have noted the confinement of the myth to specific cultural, institutional and upper class niches, who are already familiar with its message of tolerance. This poses limits to the use of al-Andalus (in the musical domain at least) as a tool for integration.

Thirdly, we need to pose some new questions: How far can the al-Andalus myth provide an ideal framework for integration? Can it withstand the new challenges looming on the horizon? What if migration trends change radically? So far, resettlement pattern from Morocco have been mostly dictated by the original problems of social justice and the distribution of wealth in the places of origin. Thus, migratory movements have been connected to power relations and economic accumulation. However, most recent research on global migration has revealed how asylum applications respond to temperature fluctuations (Missirian and Schlenker 2017). In Morocco, recent climate trends have already forced people to abandon rural areas due to sharp increases in the absolute warmest and coldest temperatures of the year-particularly in the spring and summer seasons (Filahi et al. 2016). Moreover, the 'vertiginous' pace of the climate crisis, largely due to mass consumption and deforestation, could alter the demographic balance leading to a shift from relatively free-to-move economic migrants to displaced climate refugees who have nowhere to go (Fernández et al. 2019)—a phenomenon already identified with a separate term, climigration (Ketola 2015). When the numbers become unmanageable, it might be easy for parties like Vox to transform the already perceived threat of demographic invasion into a mobilizing tool for a profoundly alarmed population (Conversi and Moreno 2019; Conversi 2020). Could a multicultural myth like al-Andalus hold on in such a context?

Despite the limitations of both the al-Andalus myth and regionalist interculturalism that is built on that myth, there is space for hope. Ultimately, beyond the rhetoric, bridge-building initiatives that seek to facilitate mutual understanding and intercultural interaction will remain in high demand in these uncertain times. For instance, cross-Mediterranean musical encounters are not simply about displaying otherness but about crafting a space in which Andalusian and Moroccan cultures might interact and converge. Music provides such a space for coming together and a unique point of contact between communities that can rise above perceived cultural or religious incompatibilities. Finally, more research needs to be carried out on strengthening cultural and musical bridges, their relative successes and ultimate consequences. As vast areas of knowledge need to be brought together to address the existential problems of the new millennium, disciplinary bridges need also to be crossed to achieve this vital task.

Author Contributions: Authors both co-wrote the paper and shared equally in its creation. All authors have read and agreed to the published version of the manuscript.

Funding: Some of this research received funding as part of the project 'Un modelo de prosopografía parlamentaria en perspectiva comparada' (HAR2014-53974-P), and the European Research Council-funded project 'Past and Present Musical Encounters across the Strait of Gibraltar' (MESG_758221).

Acknowledgments: We would like to warmly thank Tariq Modood for kindly providing highly relevant advice on the issue of multiculturalism versus interculturalism. Also we would like to thank members of the Fundación Tres Culturas for their insights and time, and the reviewers for their useful comments.

Conflicts of Interest: The authors declare no conflict of interest. 


\section{References}

Aix Gracia, Francisco. 2014. Flamenco y poder. Un estudio desde la sociologìa del arte. Madrid: Fundación SGAE.

Akasoy, Anna. 2010. Convivencia and its discontents: Interfaith life in al-Andalus. International Journal of Middle East Studies 42: 489-99. [CrossRef]

Armstrong, Karen. 2004. A Short History of Myth, 1st ed. Edinburgh: Canongate Books.

Armstrong, John A. 2017. Nations Before Nationalism, 2nd ed. Chapel Hill: University of North Carolina Press. First Published 1982.

Barber, Benjamin R. 1995. Jihad vs. McWorld: How Globalism and Tribalism Are Reshaping the World, 1st ed. New York: Times Books/Ballantine Books.

Billig, Michael. 1995. Banal Nationalism. London/Thousand Oaks: Sage.

Bonnett, Alastair. 2006. The Americanisation of anti-Racism? Global power and hegemony in ethnic equity. Journal of Ethnic and Migration Studies 32: 1083-103. [CrossRef]

Calderwood, Eric. 2014a. The invention of al-Andalus: Discovering the past and creating the present in Granada's Islamic tourism sites. Journal of North African Studies 19: 27-55. [CrossRef]

Calderwood, Eric. 2014b. "In Andalucía, there are no foreigners": Andalucismo from transperipheral critique to colonial apology. Journal of Spanish Cultural Studies 15: 399-417. [CrossRef]

Calderwood, Eric. 2018. Colonial Al-Andalus: Spain and the Making of Modern Moroccan Culture. Cambridge: Harvard University Press.

Castro, Américo. 1948. España en su historia: Cristianos, Moros y Judíos. Buenos Aires: Losada.

Catlos, Brian A. 2002. Contexto y conveniencia en la corona de Aragón: propuesta de un modelo de interacción entre grupos etno-religiosos minoritarios y mayoritarios. Revista d'Historia Medieval 12: 259-68.

Chaachoo, Amin. 2011. La música andalusí: Historia, conceptos y teoría musical. Cordoba: Almuzara.

Ciantar, Philip. 2012. Musical translations across the Mediterranean. Journal of Mediterranean Studies 21: $220-429$.

Ciantar, Philip. 2016. The Ma'luf in Contemporary Libya: An Arab Andalusian Musical Tradition. New York: Routledge.

Conversi, Daniele. 1997. The Basques, the Catalans and Spain: Alternative Routes to Nationalist Mobilization. London: Hurst \& Co/Reno, University of Nevada Press.

Conversi, Daniele. 2018. The nation in the region: Flamenco and canzone napoletana as national icons in modern Spain and Italy (1880-1922). Nations and Nationalism 24: 669-94. [CrossRef]

Conversi, Daniele. 2020. The ultimate challenge: Nationalism and climate change. Nationalities Papers. Forthcoming.

Conversi, Daniele, and Sanjay Jeram. 2017. Despite the crisis: The resilience of intercultural nationalism in Catalonia. International Migration 55: 53-67. [CrossRef]

Conversi, Daniele, and Luis Moreno. 2019. Mediterráneo, mal nuestro. Agenda Pública - El País. Available online: http://agendapublica.elpais.com/mediterraneo-mal-nuestro/ (accessed on 1 November 2019).

Corfis, Ivy A. 2009. Al-Andalus, Sepharad and Medieval Iberia: Cultural Contact and Diffusion. Leiden: Brill.

Cruces Roldán, Cristina. 2003. El flamenco y la música andalusí: Argumentos para un encuentro. Barcelona: Ediciones Carena.

Davila, Carl. 2012. Music and social institutions: al-Malūf and al-Āla. International Journal of Middle East Studies 44: 785-86. [CrossRef]

Davila, Carl. 2013. The Andalusian Music of Morocco: al-ala: History, Society and Text. Wiesbaden: Reichert.

Dodds, Jerrilynn Denise, Maria Rosa Menocal, and Abigale Krasner Balbale. 2010. The Arts of Intimacy: Christians, Jews, and Muslims in the Making of Castilian Culture. New Haven: Yale University Press.

Fernández, Cayetano, María Luisa Sierra-Huedo, and David Chinarro. 2019. Climate Change-Induced Migration in Morocco: Sub-Saharian and Moroccan Migrants. In Mediterranean Mobilities: Europe's Changing Relationships. Edited by M. Paradiso. Cham: Springer International Publishing, pp. 177-95.

Fernández Manzano, Reynaldo. 1993. La música de los moriscos del Reino de Granada. In Actes du Ve Symposium International d'Etudes Morisques sur: Le V Centenaire de la Chute de Grenade, 1492 (Vol. 1). Edited by A. Temimi. Zaghwān: Ceromdi, pp. 257-74.

Fernández Manzano, Reynaldo. 2012. La música de Al-Andalus en la cultura medieval, imágenes en el tiempo. Granada: Editorial de la Universidad de Granada.

Filahi, S., M. Tanarhte, L. Mouhir, M. El Morhit, and Y. Tramblay. 2016. Trends in indices of daily temperature and precipitations extremes in Morocco. Theoretical and Applied Climatology 124: 959-72. [CrossRef] 
García, Bernabé López, and Miguel Hernando de Larramendi. 2002. Spain and North Africa: Towards a Dynamic Stability. Democratization 9: 170-91. [CrossRef]

García Cortés, Manuela. 1996. Pasado y presente de la música andalusí. Sevilla: Fundación El Monte, Monte de Piedad, Caja de Ahorros de Sevilla.

García Cortés, Manuela. 2018. La música árabe y andalusí de las dos orillas en los estudios musicológicos (ss. XVIII-XXI). Málaga: Ediciones Genal/Promotora Cultural Malagueña.

Glasser, Jonathan. 2015. Andalusi musical origins at the Moroccan-Algerian frontier: Beyond charter myth. American Ethnologist 42: 720-33. [CrossRef]

Glasser, Jonathan. 2016. The Lost Paradise: Andalusi Music in Urban North Africa. Chicago: The University of Chicago Press.

Goldberg, K. Meira. 2019. Sonidos Negros: On the Blackness of Flamenco. Oxford: Oxford University Press.

González Alcantud, José Antonio. 2011. Social memory of a World Heritage site: The Alhambra of Granada. International Social Science Journal 62: 179-97. [CrossRef]

González Alcantud, José Antonio. 2017. Al Ándalus y lo Andaluz. Al Ándalus en el imaginario y en la narración histórica española. Córdoba: Almuzara.

Guettat, Mahmoud, María del Mar Carrillo, and Manuela Cortés García. 1999. La música andalusí en el Magreb: Simbiosis musical entre las dos orillas del Mediterráneo. Sevilla: Fundación El Monte.

Heredia Maya, José. 2004. Literatura y antropologia. Granada: Universidad de Granada.

Hutchinson, John. 2015. Golden Ages. In The Wiley Blackwell Encyclopedia of Race, Ethnicity, and Nationalism. Hoboken: Wiley Blackwell, pp. 1-3.

Infante, Blas. 1976. El Ideal Andaluz, 3rd ed. Madrid: Tucar. First Published 1915.

Joppke, Christian. 2004. The retreat of multiculturalism in the liberal state: theory and policy. The British Journal of Sociology 55: 237-57. [CrossRef]

Karl, Brian. 2012. Across a Divide: Mediations of Contemporary Popular Music in Morocco and Spain. Ph.D. dissertation, Columbia University, New York, NY, USA.

Karl, Brian. 2014. Across a divide: Cosmopolitanism, genre, and crossover among immigrant Moroccan musicians in contemporary Andalusia. Migration Studies 3: 111-30. [CrossRef]

Ketola, Tarja. 2015. Climigration: How to plan climate migration by learning from history? Global Environment 8: 410-45. [CrossRef]

Kymlicka, Will. 1996. Multicultural Citizenship: A Liberal Theory of Minority Rights. Oxford: Oxford University Press.

Kymlicka, Will, and Alan Patten, eds. 2003. Language Rights and Political Theory. Oxford: Oxford University Press.

Leblon, Bernard. 2005. Gitanos y moros en la vuelta musical al Mediterráneo hacia Andalucía, un lugar de encuentro entre Oriente y Occidente. O Tchatchipen: Lil ada Trin Tchona Rodipen Romani Revista Trimestral de Investigación Gitana 49: 33-39.

Leerssen, Joep. 2015. The nation and the city: Urban festivals and cultural mobilisation. Nations and Nationalism 21: 2-20. [CrossRef]

Lentin, Alana. 2014. Post-race, post politics: the paradoxical rise of culture after multiculturalism. Ethnic and Racial Studies 37: 1268-85. [CrossRef]

Lentin, Alana, and Gavan Titley. 2011. The Crises of Multiculturalism: Racism in a Neoliberal Age. London: Zed Books Ltd.

Leoussi, Athena S., and Steven Grosby, eds. 2006. Nationalism and Ethnosymbolism: History, Culture and Ethnicity in the Formation of Nations. Edinburgh: Edinburgh University Press.

Levrau, François, and Patrick Loobuyck. 2018. Introduction: Mapping the multiculturalism-interculturalism debate. Comparative Migration Studies 6: 13. [CrossRef] [PubMed]

Machin-Autenrieth, Matthew. 2017. Flamenco, Regionalism and Musical Heritage in Southern Spain. London: Routledge.

Machin-Autenrieth, Matthew. 2019. Spanish musical responses to Moroccan immigration and the cultural memory of al-Andalus. Twentieth Century Music 16: 259-87. [CrossRef]

Machin-Autenrieth, Matthew. 2020. The dynamics of intercultural music making in Granada: 'Everyday' multiculturalism and Moroccan integration. Ethnomusicology. Forthcoming.

Martin, David. 2014. Religion and Power: No Logos without Mythos. Farnham: Ashgate Publishing, Limited. 
Matute, Fran G. 2019. José Manuel Cervera: 'La extrema derecha europea está hoy disfrazada de nacionalismo'. Jot Down: Contemporary Culture Magazine. Available online: https://www.jotdown.es/2019/04/jose-manuelcervera-la-extrema-derecha-europea-esta-hoy-disfrazada-de-nacionalismo/ (accessed on 1 November 2019).

May, Stephen, Tariq Modood, and Judith Squires, eds. 2004. Ethnicity, Nationalism, and Minority Rights. Cambridge: Cambridge University Press.

Mazower, Mark. 2005. Salonica, City of Ghosts: Christians, Muslims and Jews, 1430-950. New York: Alfred A. Knopf.

Menocal, Maria Rosa. 2012. The Ornament of the World: How Muslims, Jews, and Christians Created a Culture of Tolerance in Medieval Spain. New York: Back Bay Books.

Menocal, Maria Rosa, Raymond P. Scheindlin, and Michael Sells, eds. 2000. Al-Andalus. Cambridge: Cambridge University Press.

Missirian, Anouch, and Wolfram Schlenker. 2017. Asylum applications respond to temperature fluctuations. Science 358: 1610-14. [CrossRef]

Modood, Tariq. 2005. Multicultural Politics: Racism, Ethnicity, and Muslims in Britain. Edinburgh: Edinburgh University Press.

Modood, Tariq. 2013. The Strange Non-Death of Multiculturalism. Fiesole: EUI Max Weber, Programme.

Modood, Tariq. 2014. Understanding 'Death of Multiculturalism' discourse means understanding multiculturalism. Journal of Multicultural Discourses 9: 201-11. [CrossRef]

Modood, Tariq. 2018. Interculturalism: Not a new policy paradigm. Comparative Migration Studies 6: 22. [CrossRef] [PubMed]

Modood, Tariq, Pragna Patel, and Stacey Gutkowski. 2010. From multiculturalism to multifaithism? A panel debate. Studies in Ethnicity and Nationalism 10: 304-22. [CrossRef]

Nair, Parvati. 2006. Rumbo al norte. Inmigración y movimientos culturales entre el Magreb y España. Barcelona: Edicions Bellaterra.

Nye, Malory. 2007. The challenges of multiculturalism. Culture and Religion 8: 109-23. [CrossRef]

Ossewaarde, Marinus. 2014. The national identities of the 'death of multiculturalism'discourse in Western Europe. Journal of Multicultural Discourses 9: 173-89. [CrossRef]

Paetzold, Christopher. 2009. Singing beneath the Alhambra: The North African and Arabic past and present in contemporary Andalusian music. Journal of Spanish Cultural Studies 10: 207-23. [CrossRef]

Parekh, Bhikhu. 2001. Rethinking multiculturalism: Cultural diversity and political theory. Ethnicities 1: 109-15. [CrossRef]

Poché, Christian. 2005. La Musica Arabigo-Andaluza. Madrid: Akal Ediciones.

Reynolds, Dwight F. 2009a. Music in medieval Iberia: Contact, influence and hybridization. Medieval Encounters 15: 236-55. [CrossRef]

Reynolds, Dwight F. 2009b. The re-creation of medieval Arabo-Andalusian music in modern performance. Al-Masaq 21: 175-89. [CrossRef]

Shamsie, Muneeza. 2015. Restoring the narration: South Asian English writing and Al-Andalus. In Imagining Muslims in South Asia and the Diaspora: Secularism, Religion, Representations. Edited by Claire Chambers and Caroline Herbert. Abingdon and New York: Routledge, pp. 59-69.

Shannon, Jonathan Holt. 2012. Studying the music of North Africa Roundtable- Introduction. International Journal of Middle East Studies 44: 775-78. [CrossRef]

Shannon, Jonathan Holt. 2015. Performing al-Andalus: Music and Nostalgia across the Mediterranean. Bloomington: Indiana University Press.

Smith, Anthony D. 1991. National Identity. Hammondsworth: Penguin/Reno: University of Nevada Press.

Smith, Anthony D. 1998. Nationalism and Modernism: A Critical Survey of Recent Theories of Nations and Nationalism. London: Routledge.

Smith, Anthony D. 1999. Myths and Memories of the Nation. Oxford: Oxford University Press.

Smith, Anthony D. 2000. National identity and myths of ethnic descent. In Nationalism: Critical Concepts in Political Science. Edited by Anthony D. Smith, Anthony D. and John Hutchinson. River Thames: Routledge, pp. 1394-429.

Smith, Anthony D. 2003. Chosen Peoples: Sacred Sources of National Identity. Oxford: Oxford University Press.

Smolicz, Jerzy J. 1995. The emergence of Australia as a multicultural nation an international perspective. Journal of Intercultural Studies 16: 3-23. [CrossRef] 
Soifer, Maya. 2009. Beyond convivencia: Critical reflections on the historiography of interfaith relations in Christian Spain. Journal of Medieval Iberian Studies 1: 19-35. [CrossRef]

Taylor, Charles. 1994. Multiculturalism: Examining the Politics of Recognition (ed. by Amy Gutmann). Princeton: Princeton University Press.

Taylor, Charles. 2012. Interculturalism or multiculturalism? Philosophy E Social Criticism 38: 413-23.

Vertovec, Steven, and Susanne Wessendorf. 2010. Introduction: assessing the backlash against multiculturalism in Europe. In The Multiculturalism Backlash. River Thames: Routledge, pp. 11-41.

Washabaugh, William. 2013. Flamenco Music and National Identity in Spain. Aldershot: Ashgate.

Wolf, Kenneth Baxter. 2009. Convivencia in Medieval Spain: A Brief History of an Idea. Religion Compass 3: $72-85$. [CrossRef] 